\title{
Education in the Perspective of Hadits (Analysis of Education in the Dimensions of the Hadith)
}

\author{
M. Chalis ${ }^{1}$, Syahril ${ }^{2}$ \\ Ar-Raniry State Islamic University-Banda Aceh ${ }^{1}$, Serambi Mekkah University-Banda Aceh ${ }^{2}$ \\ \{m_chalis@yahoo.com ${ }^{1}$,syahril@serambimekkah.ac.id $\left.{ }^{2}\right\}$
}

\begin{abstract}
Hadith in the context of education is very important to be studied and analyzed as an understanding of the concept of education. This paper tries to look at education through the perspective of the hadith, where the hadith becomes the second source after the Quran which is the main and most important source of Islam. Understanding educational hadiths explaining the content of the hadiths related to education is a very urgent matter to know and used as a reference in the world of education. Many things or topics of hadith that talk about education; educational goals; educator; learners; and matters relating to the educational process both the educational method and educational material.
\end{abstract}

Keywords: Hadith, Perspective, Education

\section{Introduction}

Talking about science in an Islamic perspective, it is different from other Shari'a or manmade laws and regulations. Islam is very concerned, respects and upholds the dignity of knowledge and people who have knowledge, as the word of God in various verses in the Qur'an. One of them is in the surah al-Mujadalah verse 11 "Surely Allah will elevate the level of those who believe among you and those who are given some degree of knowledge".

Through this verse, it can be stated that in the teachings of Islam, the notion of science is not only based on the amount of knowledge learned. But true science is science that is felt to be beneficial by humans in general. Thus, Islam is very concerned about this aspect because it is directly related to the needs and improvement of the standard of human life, the formation of civilization and so forth. The Quran invites Muslims to seek, obtain, and study knowledge and wisdom and place people who have high knowledge at a very high degree. Islam places knowledge in a very important position, so finding knowledge is obligatory. Islam also teaches that in applying knowledge applies the principle of not knowing the boundaries, dimensions, space and time. This means that wherever and whenever (not knowing the limits of place and time) we can learn (Heri Jauhari Muchtar, 2005: 13).

Because of the importance of science, it is often considered a branch of truth, but the most important aspect of scientific truth is not the highest and final, but nevertheless it changes continuously. Continuity of scientific research and discoveries, means that what is today called scientific could be different later on, caused by the existence of new elements in human science. Finally, although human efforts are carried out through members of the human bodies 
including its limitations, scientific facts are still limited by various limitations, especially in viewing the authenticity of the universe.

In addition to the scholars also placing knowledge as a very special position, among them is the shaykh of the hadith experts, Imam Bukhari rohimahullah, this is proven because he made a book in his holy book entitled Kitabul 'Ilmi which he placed after the Kitabul Iman. The hadiths that state the importance of the position of knowledge are as narrated by Mu'awiyah r.a. he said: I heard the Messenger of Allah. said: "Whoever Allah wants good to him, surely Allah will understand him about (his) religion" (HR. Muttafaqun 'alayhi).

This Hadith shows that the position of science is very important for those who study it, so that no doubt Imam an-Nawawi (1999) in his book Riyadhush Saliheen in the discussion on "The Excellence of Science" lists this Hadith as the first Hadith. In the book Imam an-Nawawi said: "This Hadith shows the virtue of knowledge (religion) and the virtue of studying it, as well as the suggestion to seek knowledge". Thus understanding of religion is among the greatest goodness that God gives to His servants. And people who do not want tafaqquh fiddiin (study and understand their religion) are forbidden from various goodness.

The hadith is the basis of Islamic education after the Quran by making the Prophet Muhammad. As an example to his people, "Indeed, the Prophet (s) was a good role model" (QS. Al-Ahzab [33]: 21). In the early course of the spread of Islam, the Prophet Muhammad teach and practice good attitudes and behaviors to his wife and friends. Then, the friends also practice it and then teach it to others (Ramayulis, 2007: 123). So, inevitably, the era of the Prophet, it succeeded in generating to a superior generation in the field of morals, religious attitudes (spiritual), personality (morals), intellectual and social. This generation became a pioneer to pave the way for the next generation in developing and enhancing human dignity.

Prophet Muhammad SAW as the last prophet sent by Allah was in charge of perfecting the teachings of the previous Prophets to bring back to the teachings of monotheism, namely the rationale of Allah. For this reason, the existence of the Prophet Muhammad as a Prophet and teacher for his friends have been prepared and designed by Allah in conveying his apostolic mission. "Indeed, Allah has given gifts to believers when (Allah) sent an Apostle (Muhammad) in their midst from among themselves, who read to them His verses, purified (their souls), and taught to them the Book (Al-Quran) and Wisdom (Sunnah), although before, they were really in a real error "(See QS Al-Jumu'ah [62]: 2). Through the above verse, it shows that the Prophet Muhammad sent by Allah to his people to instill knowledge while purifying their souls. Sanctifying means cleansing from the bad qualities that were the habits of most of the Makkah community at that time, such as shirk, envy, fear and other bad behavior such as drunk drinking, depriving the rights of others and others.

Prophet Muhammad SAW dismantles the mindset of the pagans until they realize their obligations to worship Allah as creator, regulator, and maintainer of humanity. Purification of the soul and awareness of the attitude of monotheism carried out by the Prophet Muhammad. (See Q.S. Ali Imran [03]: 164) with teaching and education taking into account the situation and condition of the community at that time.

$\mathrm{He}$ in his position as an educator, he was not only oriented to the domains of creative skills, but also covered the dimensions of the realm of taste and intention. Even more than that the Prophet Muhammad has shown perfection as an educator as well as a teacher, because he in the implementation of learning has covered all aspects that have been determined by educational experts that education must be cognitive (the Messenger of Allah. Transmit knowledge and culture to others), is psychomotor (Rasulullah Saw practice physical skills to the friends), are affective (Rasulullah Saw always instill values and belief in his friends). For this reason, the task of educating is not work that can be left to just anyone. However, the task 
must be left to experts, namely those who have the competence as professional educators. This was hinted by the Prophet Muhammad in a saying: "If an affair is left not to the expert, then the destruction is waiting" (H.R. Bukhari). Based on this hadith, experts agree that the characteristics of professional teachers are mastering the field of science they will teach, and mastering how to teach it effectively and efficiently and having good character (akhlak alkarimah) (Mochtar Buchori, 1994: 30).

On the other hand, a professional teacher is a person who never stops learning, reading and researching, so that the knowledge he teaches is kept up to date, in accordance with the times. In other words, he must continue to study, study and research throughout his life. This is in line with the hadith of the Prophet Muhammad SAW: "Seek knowledge from cradle to grave". A teacher, who stops learning, not only will be left behind by his students, but will be misleading and confusing. Because it may be a theory or concept that was taught to their students apparently no longer true.

The necessity to master this teaching technique has also been mastered by Rasulullah Saw. In this case we can see in the historical record of his success in educating friends who have deep religious knowledge, mentality and noble personality shows that he has succeeded in becoming a professional and successful teacher. Ideally, every teacher (educator) can appear as what has been exemplified by the Prophet. In the educational process, it means that every educator must try to be an example of their students. Good example in all aspects and not vice versa. By imitating the attitude of the Prophet in every case it is imperative for all people, including educators or teachers, if they imitate the strategy exemplified by the Prophet, it will undoubtedly obtain success as expected.

In terms of education of the Prophet has provided many lessons for educators regarding the method of education, which can be implemented by educators in formal institutions (schools) or at home by parents who provide education to their children. An educator cannot educate his students with the main character except if he has the main character and he cannot improve them unless he is righteous, because students will take more examples from him than take his words (Muhammad ibn Ibrahim al- Hamd, 2002: 27).

In essence, in educational institutions students are thirsty for role models, because most of the results of personality formation are exemplary by the educators. At home, exemplary will be obtained from both parents and from adults in the family. As learners, students definitely ensure that everything they see and hear from the ways of their educators is true. Therefore educators should display the morals of the mercy as taught by the Prophet Muhammad.

Hadith as the second source of Islamic teachings after the Quran has been agreed upon by almost all Muslims as one of the laws that must be obeyed. For this reason, Hadith has functionalist means to explore the concept of education. Whereas in the world view of Islamic education, education is a very important part in navigating human life, because it is through education that humans will exist and prevail on this earth. For that reason, in Malik Fajar's view, the problem of education is a problem that is never completely discussed, because it concerns human problems in order to give meaning and normal direction to the existence of fitrinya (Yunus Hasyim Syam, 2005: x).

Speaking of the notion of education, in this case An-Nahlawi said that the word education comes from Arabic, which is from the root of the word raba-yarbu-tarbiyah, which means 'increasing' and 'developing', or rabia-yarba, which is compared with the word khafiya yakhfa. The meaning contained in gaba-yarbu is additional and developing, and gaba-yarubbu which is compared with the word maddayamuddu means to improve, manage interests, regulate, maintain, and pay attention (An-Nahlawi, 1996: 20). 
While Imam Al-Baidhawi gave the definition of tarbiyah, namely conveying something little by little so that it was perfect. According to Al-Maraghi, the word rabbun consists of two letters, namely "ra" and "ba" tasydid which is a fraction of the root word tarbiyah which means "education and nurture". In addition, this word includes many meanings such as "power, tools of accountability, improvement, improvement". This word is also for an impression, majesty, power and leadership (Musthafa Al-Maraghi, t.th: 30).

The term tarbiyah also comes from the root word (rabiya, yarba) which means to make something big. As for the Hadith related to the concept of Tabiyah, for example the Hadith narrated by Bukhari from Ibn Abbas, namely: "Be you, educating educators, fiqh experts, and knowledge experts. And it is called education if someone has educated humans with knowledge, from the smallest to the highest. "(HR. Bukhari). If examined semantically, the above Hadith has a meaning as a process of transformation of knowledge from the basic level to the next level based on high enthusiasm in understanding and realizing his life so that piety, character and noble person.

Islamic education both as a concept and as an activity that moves in the context of fostering a complete and complete personality requires a solid foundation. Because the basis is a foundation on which to stand or stand something so that it can stand firmly (Nur Uhbiati, 1997: 24). Furthermore, Zakiah Darajat (1992: 19), said that Islamic education as an effort to form humans must have a foundation of faith, and to that basis all activities and all formulations of the objectives of Islamic education are linked. This is what shows something urgent in education in order to have strength and continuity and to survive must have a solid foundation and have strong strength.

In the view of Abuddin Nata and Fauzan (2005) said, the basis and foundation are very influential on the pattern of development of something that will be formed in the next process. He further illustrated, a luxury house that has a modern architecture will quickly collapse if it is not based on a strong cement castings as a basis in establishing the building. What is the use of a luxury home without having a solid building foundation that ultimately can not last long? Likewise with education, serious consideration is needed on the basis of the founding of education. From this foundation, education will stand majestically and continue to survive in various eras it faces in the future.

Based on the above, the basis of Islamic education must be considered comprehensively and thoroughly in navigating the movements and steps of educational development. For this reason, the study of Islamic education cannot be separated from the foundation related to the source of Islamic teachings themselves, namely the Quran, Hadith and Ijtihad conducted by the scholars. This is as the words of the Prophet Muhammad. which is explained in the Hadith, namely: "I leave in the midst of you two things, you will not go astray as long as you hold fast to both, namely: the book of Allah and the sunnah of His Prophet" (Narrated by Malik and Hakim). The above hadith is the will of the Prophet Muhammad Saw to his people and delivered it in the last moments of his life. In the will it is stated that the Hadith is the second guide after the Quran.

\section{Result and Discussion}

Education is a process of forming human personality. Therefore, education is needed by everyone, both men and women. Besides that, as a process, education does not only take place at one time, but the education process must take place continuously and continuously and be carried out throughout life. Therefore, Islam gives a very great and special attention to 
education. The education process can take place as long as humans live both inside and outside of school. With a no-limit and age limit policy, we encourage each individual to become the subject responsible for self-education. Therefore, in practice education takes place regardless of sex, both men and women. This is as explained in a Hadith of the Prophet (PBUH), namely: "Demanding compulsory knowledge of every Muslim male and female" (H. R. Ibnu Majah and Baihaqi).

In addition, learning also knows no time limit; meaning there is no term too late or too early to learn. This also means that there is no concept that is too old to learn. The process and time of education lasts a lifetime from the womb until humans die. This basis also means giving pedagogical-psychological responsibilities to parents, especially mothers who are pregnant to develop their content psychologically-physically. This is as explained in a Hadith: "Seek knowledge from infancy to the grave" (H. R. Baihaqi).

Furthermore, in the view of Ramayulis (2007) explained, that the limits of education in Islam contain several restrictions:

\subsection{Broad Limits}

Limitation in the broadest sense is all forms of learning experiences that are passed by students with all the circumstances and throughout life. As for what constitutes a limitation of education in the broadest sense is as follows:

a. Education lasts a lifetime.

b. The educational environment is everything that is outside the student self.

c. All forms of activities ranging from unintentional self to the programmed.

d. The purpose of education is related to each learning experience, and

e. All activities are not limited by time and space.

\subsection{Narrow Limits}

Limitation of education in the narrow sense is the learning process carried out in formal education institutions (madrasas / schools). Within these narrow limits, Islamic education appears in the form of a complete system. The narrow educational limits are as follows:

a. The period of education is limited

b. The educational environment takes place in schools / madrasas

c. Forms of activity are programmed, and

d. The purpose of education is determined by the school / madrasa

\subsection{Limited Broad Limits}

The purpose of limited educational limits is any conscious effort undertaken by families, schools, communities and government through teaching and training activities carried out in formal (school / madrasah) non-formal (community) and in-formal (family) educational institutions and carried out throughout life, in order to prepare students to play a role in various lives. The limits of education in the broadest limited sense are as follows:

a. The lifetime of education but educational activities are limited to a certain time.

b. The education environment is also limited.

c. Forms of educational activities take the form of education, teaching and training.

d. The purpose of education is a combination of developing students' potential with social demand (Ramayulis, 2007: 67). 
The purpose of educational goals is expected changes in the subject of students after experiencing the educational process, both in the behavior of individuals and their personal lives as well as the life of the community and the natural surroundings in which individuals live, other than as a direction or direction in the implementation of education, also functions as a controller and evaluate the success education process.

For this reason, education is a central and urgent problem in education, because without a clear formulation of the purpose of education, actions become irregular, without direction, can even violate rules or misjudgment and are futile. Therefore, the formulation of goals clearly and clearly becomes the core of all pedagogical thinking and philosophical contemplation (Kartini Kartono, 1992: 204).

The purpose of Islamic education in general is for people who are educated to become pious servants of God, as responsible leaders, perfect humans, obtain the salvation of the world and the hereafter. For this reason, in Al-Syaibani's view, the purpose of education is the desired change through the educational process, both in the individual's behavior in his personal life, in the life of the community and surrounding nature and in the process of education and teaching itself as a human activity and as a proportion as human rights profession in society (Omar Mohammad, 1979: 399).

Based on the above concept, education is considered unsuccessful or does not achieve its objectives if there is no change in the students themselves after completing an educational program. In order to be measurable, before carrying out the education process clear objectives must be formulated. The formulation can be explored from the source of Islamic education, namely the Qur'an and Hadith as the main source.

\section{Conclusion}

It is undeniable that the hadith is a real reality of Islamic teachings contained in the Quran. Because the task of the Prophet. is the bearer of the treatise and explanatory content of the Quran, it means the hadith, the essence is none other than the explanation and practice of the teachings of the Quran. Hadith is an interpretation of the Quran. So, there is no doubt that the hadith is not only seen as the basis of Islamic education solely. The truth in the hadith is also in line with the truth that can be accepted by common sense and historical evidence that can be found in sharing literature.

There is no doubt about this Islamic treatise, because it has received the legitimacy of Allah and His Messenger. Whoever really holds fast to him in totality will get the glory of the world and the hereafter. If Islam is used as a way of life in every discipline and aspect of life and is no exception in terms of education, humans will receive guidance and it will definitely go on the right and right path. The education referred here is sourced from the Quran and the Hadith of the Prophet based on monotheism, the existence of integrity between faith, knowledge and charity and separating the concepts of religious knowledge and worldly science, religious education and general education.

\section{References}

[1] Abuddin Nata dan Fauzan. 2005. Pendidikan Dalam Prspektif Hadits. Jakarta: UIN Jakarta Press. 
[2] Abu Zakaria Yahaya, Al-Imam bin Syaraf an-Nawawi. 1999. Riyadhus Shalihin. Terj. achmad Sunarto. Jakarta: Pustaka Amani.

[3] An-Nahlawi. 1996. Pendidikan Islam di Rumah, Sekolah, dan Masyarakat. Terj. Shihabuddin. Jakarta: Gema Insani Press.

[4] Heri Jauhari Muchtar. 2005. Fiqih Pendidikan. Bandung: PT. Remaja Rosdakarya.

[5] Kartini Kartono. 1992. Pengantar Ilmu Pendidikan Teoritis. Bandung: Mandar Maju.

[6] Mochtar Buchori. 1994. Ilmu Pendidikan Dan Praktek Pendidikan Dalam Renungan. Jakarta: IKIP Muhamadiyah.

[7] Muhammad bin Ibrahim al-Hamd. 2002. Ma'al Mu'alim. Jakarta: Darul Haq.

[8] Musthafa Al-Maraghi. t.th. Tafsir Al-Maraghi. Beirut: Dar Al-fikr.

[9] Nur Uhbiati. 1997. Ilmu Pendidikan Islam. Bandug: Pustaka Setia.

[10] Omar Mohammad Al-Taumy Al-Saibani. 1979. Falsafah Pendidikan Islam. Terj, Hasan Langgulung, Jakarta: Bulan Bintang.

[11] Ramayulis. 2007. Ilmu Pendidikan Islam. Jakarta: Kalam Mulia.

[12] Yunus Hasyim Syam. 2005. Mendidik Anak ala Muhammad. Yogyakarta: Penerbit Sketsa.

[13] Zakiah Daradjat. 1992. Ilmu Pendidikan Islam. Jakarta: Bumi Aksara. 